\title{
AN ANALYSIS OF POPULAR JUSTICE ON POLISH FACEBOOK DISCUSSION GROUPS
}

\author{
Bartosz PŁOTKA, MA \\ bplotka.umk@gmail.com \\ Faculty of Political Science and International Studies \\ Nicolaus Copernicus University, Thorn, Poland
}

\begin{abstract}
The subject of this article is the efficiency of popular justice as the informal mechanism of public safety production on the example of Polish users of facebook.com. The investigation was based on the empirical data collected from Polish public discussion groups on the facebook website. The qualitative analysis of digital data allowed a presentation of what forms popular justice takes today and what kind of reconceptualisation it undergoes in comparison to its previous forms. The theory that backed up the study was the concept of informal institutions which allowed the most important characteristics and their changes to be demonstrated. The results show that popular justice is an ineffective mechanism of public safety production because of its selectivity and the high level of emotions related to judging people, which makes a just judgment impossible.
\end{abstract}

Keywords: popular justice, facebook.com, informal institutions, public security production, Poland, qualitative study

\section{Introduction}

No one likes to be harmed. Similarly, we feel moral discomfort when others suffer harm. In both cases, we would want that the harm would never have happened. For this reason, we demand a punishment for the oppressor, usually in the form of satisfaction or compensation for the incurred losses. We demand it because 
we also want to even up the balance of damage. In other words, we want justice. The latter, therefore becomes a kind of insurance. We feel safe because we believe that the consequence of crime is an adequate punishment and that no one wants to be punished. Practice, however, shows that the insurance is sometimes ineffective. There are people who cause damage to others despite the risk of being punished; there are situations in which we find the punishment inadequate; and there are people who avoid punishment. History shows that many people have thought about how to maximize the efficiency of punishment and how to prevent crime. History also shows that these efforts were not fully successful because the institutional solutions sometimes fail or even produce criminals (Foucault 1991, pp. 257-308). In times of intense demographic growth, hence the bigger number of committed crimes, and in times of instant access to news, the trust in formal public institutions producing safety decreases, especially when their efforts against criminality are inefficient. Theory and practice show that when formal institutions fail, informal institutions emerge to contest or to supplement them. In this article, I look at one of them: popular justice, the idea of which is to restore the primacy of justice amongst other principles of social behaviour. The article's aim, however, is to show how popular justice can change depending on the culture, milieu and environment in which it functions; especially nowadays, when many social phenomena migrate to the Internet.

Popular justice is not a new political science category. Also, it does not name something new. For instance, popular rituals of public humiliation, preceding the development of formal judicial structures, were performed in ancient Greece (Forsdyke 2011, pp. 3-4). To simplify, then, one can say that popular justice is a lynching executed by a society convinced of someone's guilt. So, what is its meaning for contemporary political science and security studies? An observer of political events would respond that only the presence of processes which could be classified as popular justice may mean a decline in trust towards public safety institutions. That observation itself makes an argument for a closer examination of the title category, especially because it is a part of a broader debate on political systems. Its input is a question: should the state maintain a monopoly on producing security? If popular justice's mechanisms were efficient then the answer would probably be no. This is why the subject of this article is the efficiency of popular justice as the informal mechanism of public safety production studied on the example of Polish users of facebook.com. To investigate it, first, I present 
the definitions of popular justice in the body of literature. Secondly, I conduct a qualitative analysis of the empirical data gathered from facebook.com (in Polish) and come up with a hypothesis: popular justice is an inefficient mechanism for producing public safety because of its selectivity and the high level of emotions related to judging people, which makes a just judgment impossible. Finally, I discuss the results and show what kind of redefinition popular justice undergoes compared to its previous forms.

\section{What Is Popular Justice?}

There are a few major understandings of what is popular justice. As noted in the introduction, in times past, it "was a forum for the expression and negotiation of tensions between elites and masses" based on public rituals such as stoning or parading on a donkey (Forsdyke 2011, pp. 40-46). In early modern Europe, it had a similar function but a small difference in form - it adopted the features of festivals, e.g. in England it was performed during Carnival and was a kind of celebration (Burke 2009, pp. 192-201). In the XVIII and XIX centuries, especially in America where there has always been a strong tradition of private violence, popular justice took the form of lynching and public executions (Berg 2011). In the relevant literature, we can also find descriptions of popular justice cases from XVIII and XX centuries, among which two are especially interesting. Dobrowolski (2017) compared the Boston events of March 1770 with those of Paris in July 1789. Foucault presented the case of the Prison Information Group (GIP') which was founded in 1971 in France to promote knowledge about prison life (Wolin 2010, pp. 606-635). In these cases, however, popular justice took the form of social revenge for the oppression of state apparatus (e.g. GIP tended to punish everyone who was connected with prison service). As such, they were rather systemic acts against the political regime than the actual acts of popular courts. Anyway, it may be noted that popular justice was always connected with various forms of ostracism and public performance of punishment.

1 The original shortcut. 
The first qualitative change of popular justice occurred in the XX Century, when people started to imitate the functions of modern court. However, Foucault (1980, pp. 1-36) observed that performing these functions was more seeming than having an actual meaning for the potential change of a priorly assumed sentence. The example he gave was the case of Brigitte Dewevre, a young girl who was raped and murdered in 1972, Bruay-en-Artois (Drake 2002, pp. 144-145; Macey 2004, pp. 105-106). After a very aggressive campaign by a local newspaper against a lawyer and his partner, who were suspected of the crime, they were castigated as guilty without proof with accompanying mob voices such as "Give him to us and we'll cut him into tiny pieces with a razor!", "I'll tie him behind my car and drive through Bruay at 60-mph!", etc. (Drake 2002, pp. 144), despite people tried to perform the functions of the actual court. According to Foucault, acting courtlike was organizing the originally chaotic social behaviour and rationalizing it through the following intuition: if the court-like procedures are maintained, then our judgment must not be wrong. That form, however, did not change the essence of popular justice which, in the cases described by Foucault, is the identification of an immediate enemy by the masses and instantaneous response to an injury, usually through the annihilation of that enemy.

Sally Engle Merry claims this form of popular justice as anarchic because it "threatens the established social hierarchy and state authority" and is separate from state law or even completely opposite to it (Merry 1993, pp. 47-49). In this sense, popular justice is countering the expansion of state law with actions performed outside the state. The author intends to challenge this understanding and proposes to comprehend popular justice as non-violent resolution of conflicts by making mutual agreements (Merry 1993, p. 4). I think this proposition, however promising, is wrong for three reasons. First, it fails on the ground of the author's assumptions. The latter form of popular justice is in the same degree anarchic like the former. Both oppose recognition of the arbitrary functions of the state, thus, ultimately, both are the antithesis of formal solutions based on state law. Second, Merry's definition has an underlying presumption that all people behave rationally so they are all capable of restraining negative impulses when harmed and calmly make rational agreements. I will demonstrate why this assumption cannot be held in the remainder. Third, in some aspects, popular justice today is not that much different from the anarchic popular justice questioned by the author, although it loses the anarchic component because people support the 
state's mechanisms instead of opposing them. To support this argument, I also look at empirical evidence in further parts of the article.

For now, I propose to follow the characteristics given by Boaventura de Sousa Santos, rather than Merry's, which frame popular justice as the minimal level of institutionalization, bureaucratization and non-professional handling of disputes directly by the people who, despite lacking or having little experience as judges, autonomously exercise social power (Santos 1982, pp. 253-254). As such, these characteristics provide a general but universal intuition as to what popular justice is. However, popular justice is always performed on the regional level by the local community, hence it must be noted that its more detailed features are relative and differ across time, region, culture, etc. For this reason, there is always a need to establish what type of popular justice we are dealing with in a given case. Because it is the antithesis of formal mechanisms, the concept of informal institutions (Helmke and Levitsky 2004, pp. 725-740) seems to be the most accurate for this process.

\section{Materials and Methods}

Nowadays, many social interactions, also these concerning political issues, migrate to the Internet, especially to the social media area. These are web pages on which users generate "social presence" (Kaplan 2010, p. 61) by publishing and exchanging digital content, usually about themselves, their lives, interests, etc. The interesting thing, then, is how do the mechanisms of popular justice look in a digital, private and highly personalized environment. Do people using computers in their houses or smartphones in "private" spheres to share information about themselves in popular justice cases behave more individually and rationally or are they subject to the crowd psychology just like during the XIX century public lynching? Is popular justice today the same or different than in previous times? Answering these questions is the reason why analyzing social media content (facebook. com in this case, as the largest social media website in the world and the most often used in Poland) seems appropriate. Facebook.com was selected from many other social networks because it is the most popular in Poland. According to the IRCenter report (2017), facebook.com is the unquestionable leader among Polish 
users of the Internet, especially when compared with the other social networks, such as YouTube.com or twitter.com, in the matter of published content and user activity (see the chart below).

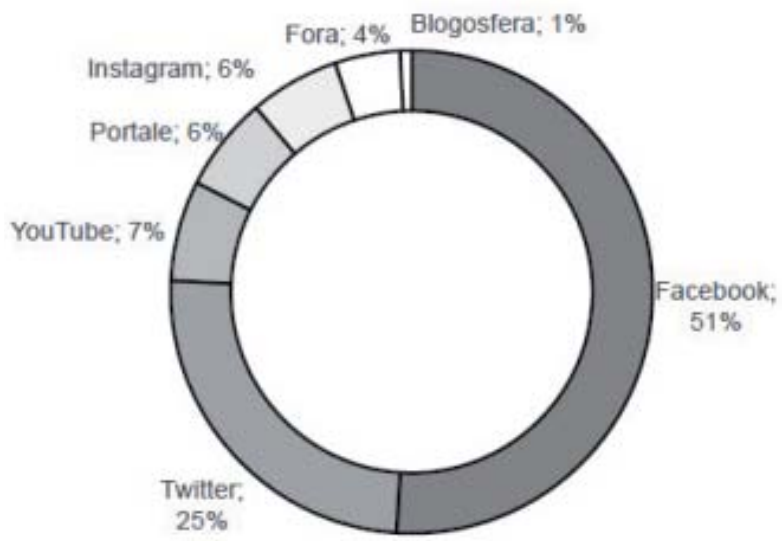

Source: IRCenter report (2017)

Fig. 1. The amount of content published in social media by Poles in 2016, $N=909342001$

To investigate the content from facebook.com, especially that concerning security issues, twenty security-related cases were randomly selected among Polish public discussion groups, e.g. Ogloszenia torunskie, Polacy na Facebooku, Ogloszenia - Wszystkie (cala Polska), Ogloszenia - cala Polska, Natemat, Wprost or Glos Wojewodzki which has a number of members (more than 10 thousand). The criteria of selection were clear: a case had to be connected with any kind of crime and had to have more than ten comments. Otherwise, the materials were not appropriate for analysis. The groups were different in terms of main topic: announcements and advertisements; members; and range: local and national. The period of selection ranged from 2015 to 2018 to address the most recent events and present the most actual trends. For this period, the goal was to choose one case per month. However, there were months in which there were no cases to report, thus more than one or two cases were chosen in the following months. As a result of the random selection, the set of cases consisted of a) fourteen reports of car accidents: usually searching for a person who did damage to a car on a parking lot or caused an accident and fled; b) three cases of harming animals: 
beating, selling skins, etc. and c) three cases of beating: causing physical damage to someone and fleeing.

In order to analyze all the cases, the technique of content analysis was applied. It was used to identify arguments, claims, standpoints or, most importantly, judgments of the people. By 'judgments' I mean their expressed opinions taking the form of sentences that they would give for the damage as judges. A criterion for qualifying comments as concerning popular justice was the condition that they had to resemble, at least to a minimal degree, considerations such as what the right thing to do is in a given situation or what should happen to the person who did some damage. This is why comments that were not connected with the investigated cases were excluded from the analysis. Moreover, I intentionally limited the number of quoted examples for the sake of decency. Language used by web surfers was very offensive, vulgar and foul. To reconcile this limitation with scientific honesty, I attach one of the most figurative and extreme examples in the form of a screenshot at the end of the article (see "Online materials" part). Eventually, it should be noted that only text comments were analyzed. Images, sounds and other kinds of content were not included in the research because their meaning is too ambiguous. Since the study is qualitative, no quantitative method was applied.

\section{Results}

The results are divided into three sections corresponding with the sets of analyzed cases. The first group of results concerns beating. In two of three cases, the oppressors had been caught and sentenced according to state law regulations. There was a large group of people who expressed that they were unsatisfied about it. They claimed that the court sentences were not just and not rigorous enough ${ }^{2}$. They claimed that the adequate punishment for the oppressors would be for them

2 Example: „Po udowodnieniu winy 25 lat za usiłowanie morderstwa... potem więzniowie powinni na nim wykonać sprawiedliwy wyrok" (source: https://www.facebook.com/ plugins/comment_embed.php?href= http\%3A\%2F\%2Fnatemat.pl\%2F235409\%2Ctrenerpersonalny-pobil-dziewczyne-dlaczego-internauci-bronia-milosza-p\%3Ffb_comment_ id\%3D1521290407997196_1521457151313855\%26comment_id\%3D15214571513 13855). 
to suffer the same crime that they committed on someone else. Another group of people demanded they be imprisoned for at least ten years and denying them any comforts such as access to information and the possibility of contact with other people. In the third case, people firstly organized an action to help the police catch the oppressor by sharing his face across various public discussion groups. Secondly, after he was captured and sentenced in court, there were three kinds of reactions: disappointment that the punishment was unjust; suggestions of heavier penalties; and, the most radical one, suggestions that the oppressor should be sentenced to death by dismembering. Usually, capital letters were used which could indicate the strength of emotion the writer felt . Interestingly, the radical reactions had a number of supporters (indicated by the number of likes). Thirdly, along with the reactions concerning the sentence and the kind of punishment, others focused on the circumstances of the situation, the oppressor's and the victim's lives ${ }^{3}$, histories, personalities, etc. Maj (2018) commented: "Web surfersdetectives look for hidden motives, analyze protagonists' lives, and want to predict the future decisions. (...) They often help to solve cases or to help victims, but also they often dig just to defend their own right. What happens on the Internet is some kind of a trial"4. However, the last group seems a minority, if compared to the number of straightforwardly judgmental people.

The second group of results addresses harming animals. The first case concerned killing and skinning cats and selling their fur. Initially, web surfers knew only that the fur was being sold but did not know by whom. The first thing they did was to report the case to the court and local police ${ }^{5}$. When these institutions dismissed it, a group of people started to look for witnesses to the transactions to gather proof and strengthen the report. The initiative was widespread across the Internet, with more than 1600 shares. It did not bring any results. Reactions to this case were different than to previous ones. There were mainly expressions

3 Example: „To nie pierwsza sprawa o naruszenie nietykalnosci cielesnej pana Miłosza. Ma on już za soba wyrok sądowy i kilka spraw w toku" (source: https://www.facebook. com/permalink.php?story_fbid $=1700771239969691 \&$ id $=114083575305140 \&$ comment_ tracking=\%7B"tn"\%3A"O"\%7D).

4 Example: „Ja się nie zgodzę że on pobił swoją dziewczynę, dla mnie jest niewinny. A wy co nie którzy oskarżacie go, czasami trzeba też wysłuchać dwie wersje i znaleść dowody na to a nie pochopnie niszczycie komuś życie tymi oskarżeniami" (source: like above).

5 https://kujawsko-pomorskie.onet.pl/fundacja-powiadomila-o-handlu-kocimi-skoramipod-chelmza/nhxgl5g 
of surprise that there are still people who believe in superstitions ${ }^{6}$. Disputants who expressed such amazement usually tried to convince others that cat fur does not heal anything, hence skinning cats is simply wrong. A smaller group claimed, however, that the fur sellers should sorely $\operatorname{die}^{7}$ or should be publicly and cruelly executed by skinning them alive and then they should be exposed as an example of what happens to people who harm animals ${ }^{8}$. Paradoxically, this reaction can be assessed as moderate when compared with reactions to the cases of animal beating. The circumstances of two investigated cases of it were similar because of their scenarios. In those situations, people almost unambiguously and unanimously reacted very aggressively. They suggested death penalties preceded by long lasting and extraordinarily brutal tortures including beating to death, limb smashing and cutting, burning, starving, dismembering, putting on a pile, etc. The most figurative comment was "eye for an eye, kill the thug" despite the animals surviving the beating and recovering afterwards. The extent of people's activities in these cases was also broader. Firstly, they started to send offensive messages, including threats, to the oppressors and to members of their families ${ }^{10}$. Secondly, they organized headhunting consisting of two parties: the larger of which tried to find them and convey them to the police, while the smaller tried to find them and punish them on the people's terms. Public messages between the attendants

6 Example: „Jessssu XXI wiek, a takie zabobony” (source: https://www.facebook.com/ permalink.php? story_fbid=1571541249813150\&id=1457362487897694).

7 Example: „Mam nadzieje, że tacy ludzie po prostu zgniją! Brak słów. Oddałabym wszystko za sprawiedliwość!!" (source: like above).

8 Example: „Takiego bydlaka złapać i dla przykładu zdjąć skórę w najbardziej bolesnym miejscu to następny kreatyn by się nie odważył" (source: https://www.facebook.com/ groups/ogloszenia.torun/ permalink/910852722401610/).

9 Example: „oko za oko! za ${ }^{* * * * *}$ c bandyte!”, „I co ? “wkurwił mnie to mu zajebałem”? Do lochu z taką kurwą co krzywdzi niewinne zwierze, połamać nogi, wybić zęby, przetrącić kręgosłup. Oko za oko ząb za ząb, najlepsze prawo w historii świata" (source: https://www. facebook.com/permalink.php?story_fbid=783761 605162729\&id=304551119750449).

10 Examples: „TY JESTES SYNKIEM TEGO Z $\mathrm{Z}^{* * * *} \mathrm{~A}$, „PO ${ }^{* * * * * * * * * * * * * *} \mathrm{~A}$ NO TO MAMY DALSZA CZESC RODZINKI POZDROW SWOJEGO STAREGO $\mathrm{CH}^{* *} \mathrm{~A}$ I PRZEKAZ AMUSI ABY UWAZALA NA WAS" (source: https://scontent.fwaw51.fna.fbcdn.net/v/t1.0-9/28379179_1649677705114828_7642169092956457267_n.jpg?_nc_ cat $=0 \&$ oh $=86691 \mathrm{a} 0 \mathrm{abd} 8180 \mathrm{~b} 782242 \mathrm{~b} 3 \mathrm{f6} 673 \mathrm{e} 260 \& o \mathrm{e}=5 \mathrm{~B} 7 \mathrm{CEC} 54)$; "twój stary to kryminalista”,

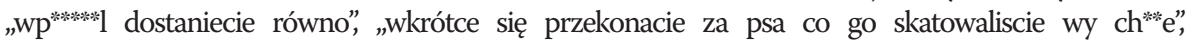
„wkrótce się przekonace już niedlaugo jest 20 osob którzy się z wami rozprawia”, ,już niedługo!!!!!!!!!”,

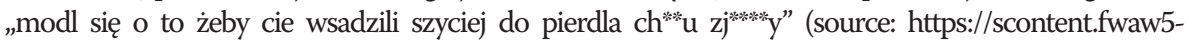
1.fna.fbcdn.net/v/t1.0-9/28468054_1649677751781490_3733213413865346487_n.jpg?_nc_ cat=0\&oh=2a7f3455506a0eed2311bd01c6a510ac\&oe=5B7E6836); etc. 
were enormously offensive and anyone who tried to rationalize the situation was either stigmatized as an enemy of the group or suspected of being an ally of the oppressors and eventually excluded from the ad hoc created communities of disputants. Also, noticeably, the majority (nearly $70 \%$ ) of the people engaged in the cases were women evincing high levels of aggressive behavior.

The last group of cases was car accidents: usually searching for people who did either unintentional or intentional damage to a car on a parking lot or caused an accident and fled. Interestingly, in these situations, the death penalty or cutting limbs off were also among the proposed solutions although not as often as in the cases of animal beating. People mostly offered help with insurance procedures or with catching a person who did damage. However helpful, not all of the proposed solutions assumed making an agreement between parties after finding a perpetrator. People straightforwardly offered their help with physical punishing him, usually by beating or destroying his property ${ }^{11}$. Also, in these cases, the reactions were very emotional but mostly because of the literally expressed feeling of helplessness caused by the police rejecting or neglecting replies to the accident reports ${ }^{12}$. People stressed that the traffic law is imprecise and inefficient and, for this reason, they wanted either to solve the cases by themselves or to support the police's efforts to look for the perpetrators ${ }^{13}$.

\section{Discussion}

The obtained results show several important tendencies. First of all, there are two contradictory trends. On the one hand, people find the state law completely useless and want to settle the disputes on their own terms, while on the other,

11 Example: „Ryj tak obić sprawcy” (source: https://www.facebook.com/groups/ ogloszenia. torun/permalink/551866264966926/).

12 Example: „Ja miałam identyczną sytuację niemal w tym samym miejscu - cały bok przerysowany na żółto... Za wycieraczką znalazłam nr rejestracyjny auta sprawcy, ale niestety świadek nie zostawił namiarów na siebie. Policja sprawcę przesłuchała i mimo, że jego auto było żółte, nr rejestracyjny się zgadzał, to Pan się wypierał twierdząc, że nie był w Toruniu. Sprawa umorzona i tyle..." (https://www.facebook.com/groups/ ogloszenia. torun/permalink/972999499520265/?sale_post_id=972999499520265).

13 Example: „Na policję z bandytami takimi !!!dożywocie dla bandytow” (source: like above). 
they support the state mechanisms by helping to catch perpetrators or to provide additional proof. The former trend is strictly anarchic because actions are performed "outside" the state but the latter one, contrary to the previous forms of popular justice, depends on trust in the state and supporting it. The anarchic trend mostly resembles the cases of popular justice described by Foucault (1980, pp. 1-36) in which an angry mob, usually created ad hoc from an accidental "community", marks a perpetrator as the immediate enemy that should be unquestionably annihilated. However, this mob claims to follow the "an eye for an eye" principle and the analysis shows that it acts otherwise by evincing much more aggressive behaviour than the original assault. Simply, the mob demands disproportionate punishments, including radically brutal ones, even for relatively minor damage, e.g. the death penalty for scratching a car. It must also be noted that any attempt to debate with the mob or propose rational thinking ended up with the immediate condemnation of anybody who tried such and accusing them of the same crime that was the subject of dispute (see the example attached to the "Online materials" section. Eventually, the anarchic trend seems to be clearly a competing type of informal institution for two reasons. First, it has a basic difference from the state law and popular justice outcomes: in Poland, the former does not prescribe the death penalty for any kind of crime. Second, it exists because people believe that the formal institutions for producing public safety are ineffective.

The major part of the supporting trend was that an accidental group of people organised itself to catch a perpetrator and hand him over to the judicial institutions. Such people believe that the state apparatus has the monopoly on violence but find it at least partially ineffective. Otherwise, they would not search for proof for the case and would not chase an oppressor. It must be mentioned that in the supporting trend, as well as in the anarchic one, it is hard to distinguish a superior, or at least specific, principle of justice. The cases were considered according to the people's intuition of what is right or wrong. The supportive trend also confirms some of Foucault's observations (1980, pp. 1-36) that the people performing popular justice mimic the actual court procedures and play the court roles such as prosecutor, attorney, judge, expert witness, etc. "What happens on the Internet is some kind of a trial" (Maj, 2018). In this sense, the popular justice mechanisms from the supportive trend produce outcomes that are convergent with the actions of the state. Therefore, they are either complementary or substitutive informal institutions, depending on people's conviction about the state's effectiveness. Based 
on this study, I assume that the people's actions were rather of the substitutive type - i.e. resulting from the belief that the state apparatus is ineffective - although it must be mentioned that an unambiguous assessment was not possible.

At some points, it is difficult to unambiguously indicate which trend was dominant. On the one hand, there was a smaller number of reactions that match the anarchic trend but on the other, they had a great number of likes, which means a great number of supporters of such a standpoint. However, the reactions from the supportive trend were more detailed and thorough because people went more deeply into the cases. They analyzed the protagonists' histories, the cases' circumstances, contexts and bases for further sentences. The functioning of social media in which comments that have more likes are better positioned is not without meaning. This is why the anarchic reactions were usually visible before the supportive ones.

Despite some doubts, I think that based on the analysis of the empirical evidence, we can draw some general conclusions concerning popular justice. First of all, the hypothesis assuming that it is the inefficient mechanism of producing public safety was confirmed, mainly because of two initially assumed reasons that it is too selective and the emotional level of judging people is so high that they are unable to make a just judgment. Similar results concerning emotions and common support for popular justice were achieved by Campos et al. (2017) who conducted a large$\mathrm{N}$ study of bullying in school. The authors claim that the agreement with popular justice is mediated by anger and moderated by the perceived ineffectiveness of social control. Specifically, the greater responsibility attributed to aggressors, the greater the anger towards them, which caused increasing agreement with popular justice. Campos underlined that "this effect was stronger for participants who believed that formal social control mechanisms were ineffective" (Campos et al. 2017, p. 52).

Another interesting thing is the selectivity of popular justice. Apart from the most obvious observation that people do not tend to judge all the cases of a given crime, there is a more absorbing general question: why do people tend to punish some crimes more than others? For example, why do people focus more on the cases of animal beating than the cases of rape or murder? Perhaps, they find an animal oppressor less dangerous than a person who is able to kill another man? - 
this would mean that popular justice today is more declarative than actually having consequences.

Another argument for popular justice's ineffectiveness is that it is not based on any actual concept of justice besides people's intuition as to what should be done in a given case; nevertheless, these intuitions are different for each judging group, hence there is no guarantee that for a particular crime there would always be a particular and adequate punishment. A sentence in popular justice is accidental. For a minor robbery, a perpetrator may lose his or her freedom as well as a hand or even life.

Another general observation is that the existence of popular justice mechanisms results from the decreasing trust in the state apparatus. However, as I demonstrated in the analysis, people do not tend towards minimizing the state's powers. Instead, they cooperate with it and increase the level of institutionalization and bureaucratization of criminal cases. Also, contrary to the aforementioned characteristics given by Boaventura de Sousa Santos (1982, pp. 253-254), they do not exercise social power autonomously but in strict dependence on the state law procedures. This is why and how popular justice stops being the anti-thesis of state law and merges with it as a result of civic engagement. The more the people support the state, the more complementary the popular justice of informal institutions becomes. Therefore, popular justice is not abolitionist but creates bases for the further development of formal legal regulations. Also, for these reasons, the aforementioned proposition of Merry's to frame popular justice as non-violent resolution of conflicts by making mutual agreements (1993, p. 4) must be rejected. The general trends concerning it depart from a libertarian spirit and eventually point more to the strengthening of the state instead of weakening it.

\section{Conclusions}

In this study, emphasis was put on the efficiency of popular justice as the informal mechanism of public safety production on the example of Polish users of facebook. com. Definitions of popular justice from the body of literature were presented and, based on qualitative analysis of the empirical data, the kind of redefinitions it undergoes nowadays was demonstrated. They were discussed in the context 
of informal institutions and their broader meaning for public safety production. The results showed that popular justice today is ineffective for the latter purpose. An advantage of this study is its empirical database collected from the largest social media website, facebook.com, which made it possible to reveal what forms popular justice can take and with what consequences. The research is not flawless, however. First of all, the results reflect trends present solely in Poland in the period between 2015 and 2018. Moreover, although the material selection was random, it may not include all the tendencies. Further studies of popular justice would also benefit from making a comparison between several countries or at least a few regions within one country. Studies of the political and legal context of popular justice, analyses of the same empirical data but with other methodology, and large- $\mathrm{N}$ investigations would only increase the body of knowledge on the topic. Therefore, further research is required.

\section{References}

Berg, M., 2011. Popular Justice. A History of Lynching in America. Ivan R. Dee Press, Chicago.

Burke, P., 2009. Popular Culture in Early Modern Europe. Ashgate Publishing, New York. Campos, M., Marques, A. G., Aguiar, T., Cardoso, S. G., Pinto, I. R., Marques, J. M., 2017. Popular Justice on Bullies: Attributions of Responsibility, Anger, and Ineffective Social Control as Fuel for Non-Normative Collective Action. Psicologia 31(2), 47-56.

Dobrowolski, P. T., 2017. Popular Justice or Why Were There No Sans-Culottes in America? Kwartalnik Historyczny CXXIV(1), 39-77.

Drake, D., 2002. Intellectuals and Politics in Post-War France. Palgrave MacMillan, New York.

Forsdyke, S., 2008. Street Theatre and Popular Justice in Ancient Greece: Shaming, Stoning and Starving Offenders Inside and Outside the Courts. Past and Present 201, 3-50.

Foucault, M., 1980. On Popular Justice: A Discussion with Maoists. In C. Gordon (ed.), Power/Knowledge. Selected Interviews and Other Writings 1972-1977. Pantheon Books, New York.

Foucault, M., 1991. Discipline and Punish. The Birth of the Prison. Penguin Books, London.

Helmke, G. and Levitsky, S., 2004. Informal Institutions and Comparative Politics: A Research Agenda. Perspectives on Politics 2(4), 725-740. 
IRCenter report, 2017. [online] Available from: http://www.wirtualnemedia.pl/artykul/90proc-polskich-internautow-korzysta-z-social-media-liderem-facebook-w-goreyoutube [Accessed 26 May 2018].

Macey, D., 2004. Michel Foucault. Reaktion Books, London.

Maj, K. 2018. [online] Available from: http://natemat.pl/235409,trener-personalny-pobildziewczyne-dlaczego-internauci-bronia-milosza-p [Accessed 28 Apr 2018].

Merry, S. E., 1993. Sorting Out Popular Justice. In S. E. Merry, N. Milner (ed.), The Possibility of Popular Justice: A Case Study of Community. Mediation in the United States. The University of Michigan Press.

Santos, B., 1982. Law and Revolution in Portugal: The Experiences of Popular Justice in Portugal after the 25th of April, 1974. In R. L. Abel (ed.), The Politics of Informal Justice, pp. 251-281. Academic Press, New York. 


\section{Appendix}

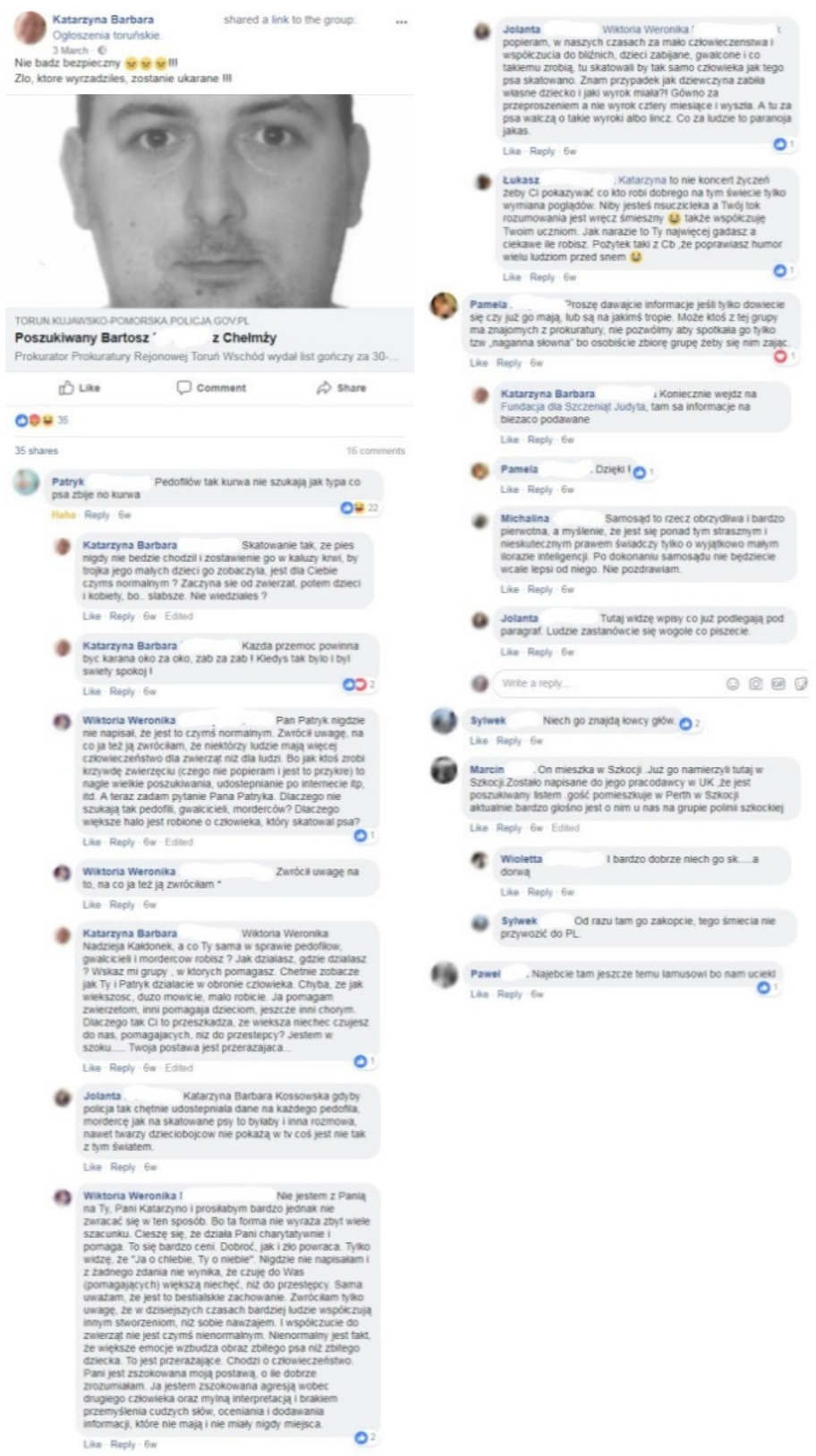

